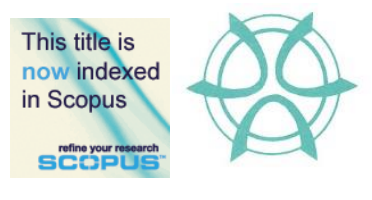

PLANNING MALAYSIA:

Journal of the Malaysian Institute of Planners

VOLUME 18 ISSUE 1 (2020), Page 45 - 55

\title{
WALKABILITY FACTORS FOR A CAMPUS STREET
}

\author{
Nor Zalina Harun ${ }^{1}$, Amanina Nashar ${ }^{2} \&$ Syahriah Bachok $^{3}$ \\ 'Institute of the Malay World and Civilization, \\ UNIVERSITI KEBANGSAAN MALAYSIA \\ ${ }^{2}$ Research Officer \\ MENTARI DESIGN \\ ${ }^{3}$ Department of Urban and Regional Planning, \\ INTERNATIONAL ISLAMIC UNIVERSITY MALAYSIA
}

\begin{abstract}
It has been reported that translating walkability is complicated, particularly the execution of its theory in planning practices. This study untangled the queries by presenting factors that makes campus interesting, walkable, and more importantly to be characterised as 'pedestrian friendly campus'. For this purpose, campus street walkability factors were analysed using factor analysis to find out the most significant measures of street walkability in the campus and its underlying items. All data has been run through SPSS beforehand and have met the assumption required for factor analysis that were formulated with the sample size of 500 respondents. The result from the study reveals that walkability factors of the campus were gratified from four significant factors that are classified as comfort, connectivity, safety and accessibility. The study reveals that proper streetscape design uncovers various potentials of the streets in forming part of a successful campus open space in the future. Moreover, the empirical findings in this research have provided a new understanding of the street function. Aside from functioning as space connectors, the streets offer broader opportunities for various pedestrian activities, which consists of passive and active activities that would contribute to the students' social and physical enhancement.
\end{abstract}

Keywords: walkability, campus design, streetscape, street 
Nor Zalina Harun, Amanina Nashar \& Syahriah Bachok

Walkability Factors for A Campus Street

\section{INTRODUCTION}

According to Speck (2012), there are four key factors of 'General Theory of Walkability'. The book elaborates on the elements that makes a city interesting, walkable to pedestrian, and more importantly it explains the characteristics of a 'pedestrian friendly' street. It stated that there are four main conditions that gratify walking needs; i) safety, ii) useful, iii) comfortable, and iv) interesting. Each of these qualities needs to be in line with one another, and none alone is satisfactory.

Meanwhile, Jacob (1993) outlined six characteristics of walkable streets. These characters include; i) pleasurable environment for a leisure walk, ii) prioritisation on pedestrian comfort, iii) streets with meanings, iv) qualities that engage the eyes, v) transparency, and vi) complementary streetscape elements. Indeed, Litman (2014) and other authors expresses the same thought as Jacob (1993) on the characters of pedestrian-friendly streets. In other studies that were conducted by Rahman, Shamsuddin and Ghani (2014), and Yap et al. (2010), proximity (distance), lack of congestion, familiarity, greenery, public amenities, maintenance and freedom of action are factors that attract pedestrian to get attached to the street's environment.

In similar studies, Lee and Moudon (2003) measured walkability by the number of travel lane and presence of crosswalk, density (Owen et al., 2004; Brian \& Susan, 2008), high density area, street directness, high connectivity (Handy, Xinyu, \& Mokhtarian, 2002), distance to non-residential spaces, land use mix (Sallis et al., 2004), street connectivity, personal safety, parks and open space. This paper therefore, suggested that walkability studies involve various measures depending on the site context itself and how the concept is understood. Walkability can also be linked with qualitative attributes such as visual quality, attractiveness, safety and comfort. Walkability represents indefinable items; it is intangible and cannot be seen physically or represented through solid elements. It depends on the context and how it is being understood (Bahari, Arhsad \& Yahya, 2013).

\section{RESEARCH BACKGROUND}

The notion of campus walkability is aimed for the students to easily reach hostels, faculties, green space and other facilities by foot. The implementation of the walkability concept is very crucial, particularly in Malaysian campus. The reason being that majority of the Malaysian universities were planned and developed in a scattered pattern (Shamsuddin, Sulaiman, \& Ja'afar, 2007). The academic building, facilities and students' hostels were distanced away and disconnected by empty spaces in between. Hence, resulting in difficulties for pedestrians' access within the campus area. Gehl and Gemzre (1996) stated that three essential principles for walkable places are i) protection, ii) comfort and iii) enjoyment. 
Protection is measured through the safety assurance against the traffic, crime and unpleasant experiences. In a walkable environment, walking is considered as a safe mode of mobility for pedestrian without being affected by the surrounding traffics. The work of Moayedi et al. (2013) identifies that walkability is measured by the quality of streetscape design, that needs to promote comfort, efficient access, permeability and pleasant experiences.

According to Miyakoda (2004), in Kansas City Departments of Planning identify walkability through five indicators of directness, continuity, street crossing, visual attractiveness and security. These qualities are reached through proper planning of streetscape. Indeed, Park (2008), and Nor Zalina and Amanina (2016) also pointed out that streetscape elements are the essential factors influencing the qualities of walkable streets. The work of Shuhana (2004), defines walkability as comfort and safety of pedestrians are achieved; with welldefined pedestrian-vehicle space and well-connected street sidewalks. Since the pedestrian perception and behaviour are highly influenced by street physical attributes (Park, 2008; Almoush et al, 2018), this validates that exploring the streetscape design is relevant to this study. Table 1 highlights various walkability studies and its concern.

Table 1 Studies Related to Walkability by Various Authors

\begin{tabular}{|c|c|c|}
\hline Authors & Walkability Concept & Concern \\
\hline $\begin{array}{c}\text { Gehl \& Gemzre } \\
\qquad(1996)\end{array}$ & $\begin{array}{l}\text { Three essential principles for walkable place are safety } \\
\text { (traffic and calamity, crime and violence), comfort } \\
\text { (positive climate, aesthetic quality and experiences) and } \\
\text { enjoyment (ability to perform various activities without } \\
\text { any obstruction). }\end{array}$ & $\begin{array}{l}\text { safety, comfort, } \\
\text { enjoyment }\end{array}$ \\
\hline Litman (2012) & $\begin{array}{l}\text { Walkability component are based on safety (traffic), } \\
\text { security (crime), comfort (sidewalk LOS and continuity, } \\
\text { buffer), conveniences (ease of access and crossing } \\
\text { activities), visual interest (attractiveness) }\end{array}$ & $\begin{array}{l}\text { Safety, security, } \\
\text { comfort, conveniences } \\
\text { and visual interest }\end{array}$ \\
\hline Miyakoda (2004) & $\begin{array}{l}\text { Measures walkability through five indicators of } \\
\text { accessibility (directness and continuity), conveniences } \\
\text { (street amenities and security), visual attractiveness, road } \\
\text { and personal safety (street crossing) }\end{array}$ & $\begin{array}{l}\text { accessibility, safety, } \\
\text { conveniences, } \\
\text { attractiveness }\end{array}$ \\
\hline $\begin{array}{c}\text { Galanis \& Nikolaos } \\
\qquad(\mathbf{2 0 1 1})\end{array}$ & $\begin{array}{l}\text { Walkability is measured through attributes of streets } \\
\text { distance, climate condition, topography, street network } \\
\text { and social factors }\end{array}$ & $\begin{array}{l}\text { distance, climate } \\
\text { condition, topography, } \\
\text { street network and } \\
\text { social }\end{array}$ \\
\hline $\begin{array}{l}\text { Ja'afar, Sulaiman, } \\
\text { \& Shamsuddin } \\
(\mathbf{2 0 1 2})\end{array}$ & $\begin{array}{l}\text { The qualities and criteria of a walkable streets are } \\
\text { comfort, attractiveness, clear direction in terms of } \\
\text { accessibility, human scale, space and symbol. }\end{array}$ & $\begin{array}{l}\text { comfort, } \\
\text { attractiveness, } \\
\text { accessibility, human } \\
\text { scale, space \& symbol }\end{array}$ \\
\hline Speck (2012) & $\begin{array}{l}\text { Gratify four main conditions; it needs to be safe, useful, } \\
\text { comfortable and interesting. Each of these qualities } \\
\text { needs to move towards together and none alone is } \\
\text { satisfactory. }\end{array}$ & $\begin{array}{l}\text { safe, useful, } \\
\text { comfortable \& } \\
\text { interesting }\end{array}$ \\
\hline $\begin{array}{l}\text { Rahimiashtiani \& } \\
\text { Ujang (2013) }\end{array}$ & $\begin{array}{l}\text { Pleasurability and attractiveness are factors that affected } \\
\text { streets walkability. }\end{array}$ & $\begin{array}{l}\text { pleasurability \& } \\
\text { attractiveness }\end{array}$ \\
\hline
\end{tabular}


Nor Zalina Harun, Amanina Nashar \& Syahriah Bachok

Walkability Factors for A Campus Street

Table 1: Studies Related to Walkability by Various Authors (cont'd)

\begin{tabular}{clc}
\hline Authors & Walkability Concept & Concern \\
\hline $\begin{array}{c}\text { Appleyard (2003); } \\
\text { Clark, Scott, \& } \\
\begin{array}{c}\text { Yiannakoulias, } \\
\text { (2013) }\end{array}\end{array}$ & $\begin{array}{l}\text { Walkability as an indicator to how satisfactory the } \\
\text { transportation system meets the needs of pedestrian. It is } \\
\text { a measure towards how friendly the environment is. }\end{array}$ & $\begin{array}{c}\text { pedestrian needs \& } \\
\text { satisfaction }\end{array}$ \\
$\begin{array}{c}\text { Moayedi et.al } \\
\text { (2013) }\end{array}$ & $\begin{array}{l}\text { Measure walkability through the quality of streetscape } \\
\text { design, land use pattern, building accessibility and social } \\
\text { safety. }\end{array}$ & $\begin{array}{c}\text { streetscape design, } \\
\text { land use pattern, } \\
\text { building accessibility } \\
\text { and social safety }\end{array}$ \\
$\begin{array}{c}\text { Litman (2014); } \\
\text { Mohd Syazwan et } \\
\text { al. (2018) }\end{array}$ & $\begin{array}{l}\text { Walkability as the quality of waking state, comprises of } \\
\text { safety, comfort and convenience attributes }\end{array}$ & $\begin{array}{c}\text { safety, comfort \& } \\
\text { convenience }\end{array}$ \\
$\begin{array}{c}\text { Afsar, Mohd Yazid } \\
\text { \& Mohd Johari } \\
\text { (2015) }\end{array}$ & $\begin{array}{l}\text { Walkability focus on liveability, accessibility, safety, } \\
\text { street connectivity by streetscape elements and } \\
\text { pedestrian activity. }\end{array}$ & $\begin{array}{c}\text { liveability, } \\
\text { accessibility, safety, } \\
\text { connectivity, } \\
\text { streetscape elements } \\
\text { and pedestrian activity }\end{array}$ \\
\hline
\end{tabular}

Table 1 highlights the majority of walkability studies and their concerns on the four major attributes of safety, connectivity, accessibility, comfort and attractiveness to obtain a walkable street. However, each attribute was measured differently due to the different understanding and background of the researcher. For instance, the quality of conveniences and accessibility refers to the same meaning whereas the operational definition may vary. Hence, this study focuses on how streetscape elements influence walkability attributes of the four indicators.

\section{METHODOLOGY}

The statistical method used for this study is a simplified factor analysis with Principal Component Analysis (PCA). The consistency of internal items as determinant of the reliability instruments was measured through Cronbach's alpha ranged from 0.6 - 0.9. For this study, campus street walkability factors were analysed using factor analysis to find out the most significant measures of street walkability in the campus and its underlying items. All of the data was processed through SPSS beforehand and met the assumption required for factor analysis were formulated with minimum sample size of 150 respondents. Adequate correlations between variables are confirmed as to ensure that all variables are appropriate for data reduction. Originally, the factorability of 42 items of four influential street walkability factors were examined. Several well-recognised criteria for the factorability of the correlation were applied.

\section{STUDY AREA}

The IIUM Gombak campus was chosen as the study area, encompassing its major and secondary road networks. The major network is the circular road; meanwhile 
the secondary road comprises the pedestrian routes connecting the mahallahs (hostels) and the kulliyyahs (faculties) as well as the students' centre (the centralised facilities provided for the students and staff such as ATM, cafeteria, convenience store and post office). The traffic direction for the vehicles on the main circular road is a one-way route. The street network involved in this study consists of routes that connects the mahallahs and the students' centre. The selected routes where questionnaires were distributed are three streets of Imam Malik Street (Street 1), Imam Abu Hanifah Street (Street 2), and Al Jamiah Street (Street 3) (Figure 1). These streets were chosen due to their level of utilisation by students of different majors for various purposes on daily basis. The street networks are also equipped with sufficient softscape and hardscape elements which support students' walking activities for various weather conditions.

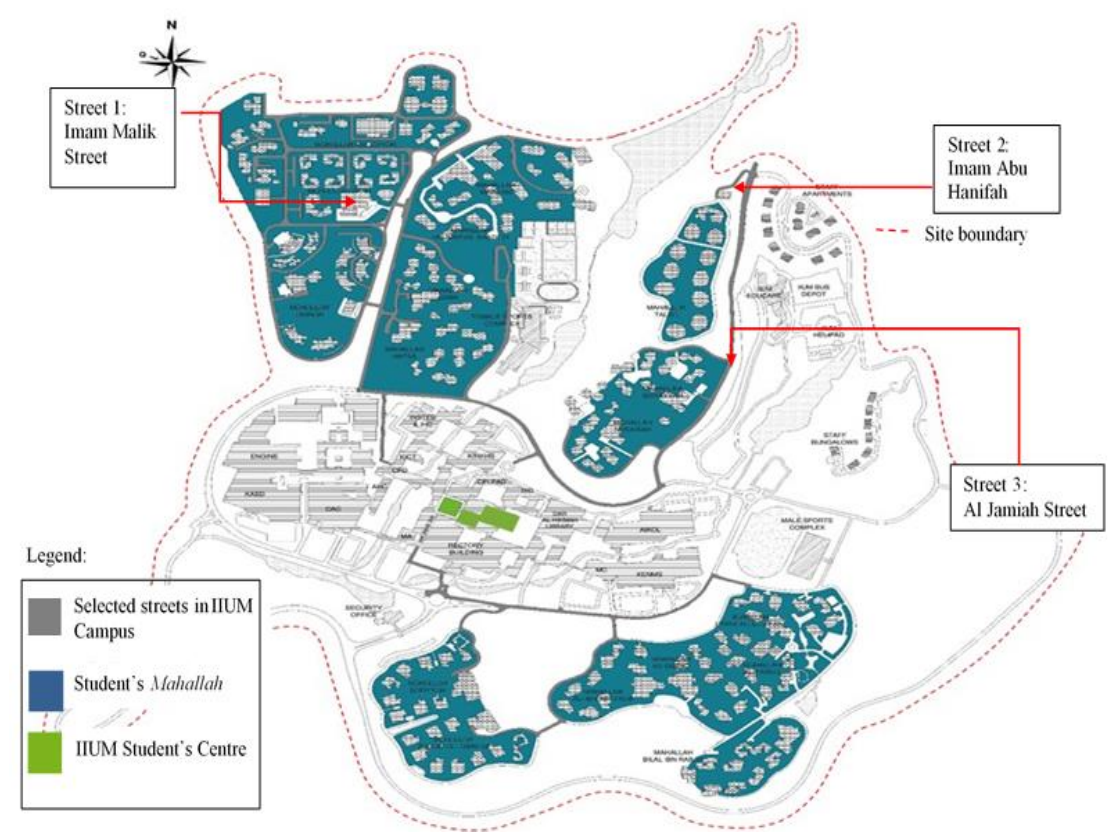

Figure 1 Selected Streets Studied

\section{FACTORS ON WALKABILITY}

A principle component analysis was computed using Promax rotation to discern the factors that influence campus street walkability based on student's satisfaction level. A series of statistical assumptions were assessed to ensure the suitability of the data for Exploratory Factor Analysis (EFA). Barlett's test of sphericity ( $\mathrm{p}=$ $0.000)$ and the Kasier-Meyer-Olkin measure of sampling adequacy $(\mathrm{KMO}=$ 0.747) all indicated that the data satisfy the threshold for Principle Component 
Nor Zalina Harun, Amanina Nashar \& Syahriah Bachok

Walkability Factors for A Campus Stree

Analysis (PCA). The PCA (with Promax rotation) generated four factors based on Kasier criterion (Eigenvalue $=1.0$ ). The factors were named as connectivity, safety comfort and accessibility.

The Cronbach Alpha of all extracted factors exceeded 0.6. Therefore, the scale achieved internal consistency. The communalities for all items exceeded 0.3 , suggesting the 'ability' of the items to load strongly in one of the factors. $\mathrm{CN}$ 16 and A44 were omitted due to low factor loadings. The total variance explained was $62.706 \%$. Table 2 shows factor loading for each item on their strongest affiliated factors.

Table 2 Rotated Component Matrix for Street Walkability Dimension

\begin{tabular}{|c|c|c|}
\hline Dimension & Items & $\begin{array}{c}\text { Factor } \\
\text { Loadings }\end{array}$ \\
\hline \multirow{9}{*}{ Comfort } & Reducing pedestrian conflict. & 0.998 \\
\hline & Buffer from vehicles noise. & 0.997 \\
\hline & Space for other pedestrian activities. & 0.816 \\
\hline & Continuous shady trees along the streets. & 0.771 \\
\hline & Spacious pedestrian sidewalk. & 0.736 \\
\hline & Seating/waiting area for pedestrian on streets. & 0.700 \\
\hline & Covered sidewalk for mobility improvement. & 0.690 \\
\hline & Bicycle lane for cyclist. & 0.652 \\
\hline & Jogging track. & 0.635 \\
\hline \multirow{12}{*}{ Safety } & Protection from rainy weather. & 0.930 \\
\hline & Protection from sun heat. & 0.916 \\
\hline & Segregation between pedestrian and vehicles route. & 0.907 \\
\hline & Underground tunnel safety. & 0.887 \\
\hline & Prioritisation for pedestrian crossing activities for streets without crossing mark. & 0.858 \\
\hline & Streets lightings functionality during night time. & 0.827 \\
\hline & Buffer between pedestrian sidewalk and vehicles route. & 0.815 \\
\hline & Streets lightings enhance mobility during night. & 0.795 \\
\hline & Prioritisation on pedestrian crossing activities for streets with crosswalk. & 0.640 \\
\hline & Decrease vehicles speed on crosswalk marking area. & 0.597 \\
\hline & Streets lightings enhance vision during night time. & 0.544 \\
\hline & Drivers reduce vehicles speed on streets without crosswalk. & 0.323 \\
\hline \multirow{9}{*}{$\begin{array}{l}\text { Access- } \\
\text { ibility }\end{array}$} & Nearest facilities should be reached able/access (bus stop etc). & 0.946 \\
\hline & Presence of multiple-choice route. & 0.766 \\
\hline & Sidewalk clearance from obstruction elements. & 0.743 \\
\hline & Crosswalk mark need to be visible during night time. & 0.741 \\
\hline & Increase signage legibility for night time use. & 0.739 \\
\hline & Enhance signage legibility to ease wayfinding. & 0.632 \\
\hline & Streets corner should be clear from trees height/obstruction. & 0.607 \\
\hline & Trees planted along sidewalk clearly direct my way. & 0.585 \\
\hline & Provide crosswalk mark at each main street junction. & 0.580 \\
\hline \multirow{5}{*}{$\begin{array}{l}\text { Connect- } \\
\text { ivity }\end{array}$} & Sidewalk should consider the nearest distance to reach destination. & 0.842 \\
\hline & Sidewalk design should properly connect. & 0.755 \\
\hline & Sidewalk should be provided on both sides of streets. & 0.703 \\
\hline & Pedestrian short cut route. & 0.628 \\
\hline & Small stop point/meeting area. & 0.621 \\
\hline
\end{tabular}


Diagram 1 presents street walkability factors gathered from survey. The suggested names for the subthemes were i) Street and Sidewalk Zoning as well as ii) Decrease pedestrian conflict. Meanwhile, three subthemes were extracted from safety (S) factor were named as i) vision at night ii) traffic safety and iii) physical safety. Three subthemes were extracted from accessibility (A) factor, namely i) permeability / directness ii) ease of movement iii) access to facilities. Two subthemes were extracted from connectivity (C) factor, which were i) sidewalk connectivity and ii) time/distance.

\section{DISCUSSION}

The result from the study suggests that walkability factors of the campus gratify four significant factors classified as comfort, connectivity, safety and accessibility. The result obtained reveals that comfort factor is more significant than safety, accessibility and connectivity factors. The significance of comfort factor is suggested to be associated with the execution of street zoning and the presence of amenities along the street. The execution of street zoning is implemented through well-defined space division and proper composition of streetscape elements on the street. Sidewalk spaces should only be utilised for walking activities. Other pedestrian activities such as sitting or waiting needs to be placed within the furnishing zone. Amenities are another essential aspect found to be significant in this study, in which they are considered to be a contributing factor that increases the level of pedestrian physical comfort. Moreover, reducing conflict among pedestrians helps to enhance pedestrian comfort as well. The result suggest that spacious sidewalk is capable of easing pedestrians' movement which would avoid them from the need to walk on the vehicle's lane. Pedestrian comfort is, therefore, increased when there is less conflict among pedestrians.

The second prominent factor of walkability in campus area is safety. The results suggest the four criteria could improve pedestrian safety in IIUM Campus include; i) segregation between pedestrian and vehicle route, ii) the presence of crosswalk marking, iii) composition of planting elements and iv) lighting luminance. The segregation between pedestrian and vehicle route provides a barrier between pedestrians and vehicles. This reduces the number of conflicts between pedestrians and vehicles on the street. A reduction in pedestrian-vehicle conflicts resulted in decreased amount of traffic collision. Crosswalk marks should be made available at the main street junctions as to ease pedestrian crossing movements. Planting elements such as shrub should function as a barrier to control pedestrian crossing movements within the street area. Lighting luminosity, location and types of lighting on the streets are important as to improve pedestrian safety during especially in night time. 
Nor Zalina Harun, Amanina Nashar \& Syahriah Bachok

Walkability Factors for A Campus Street
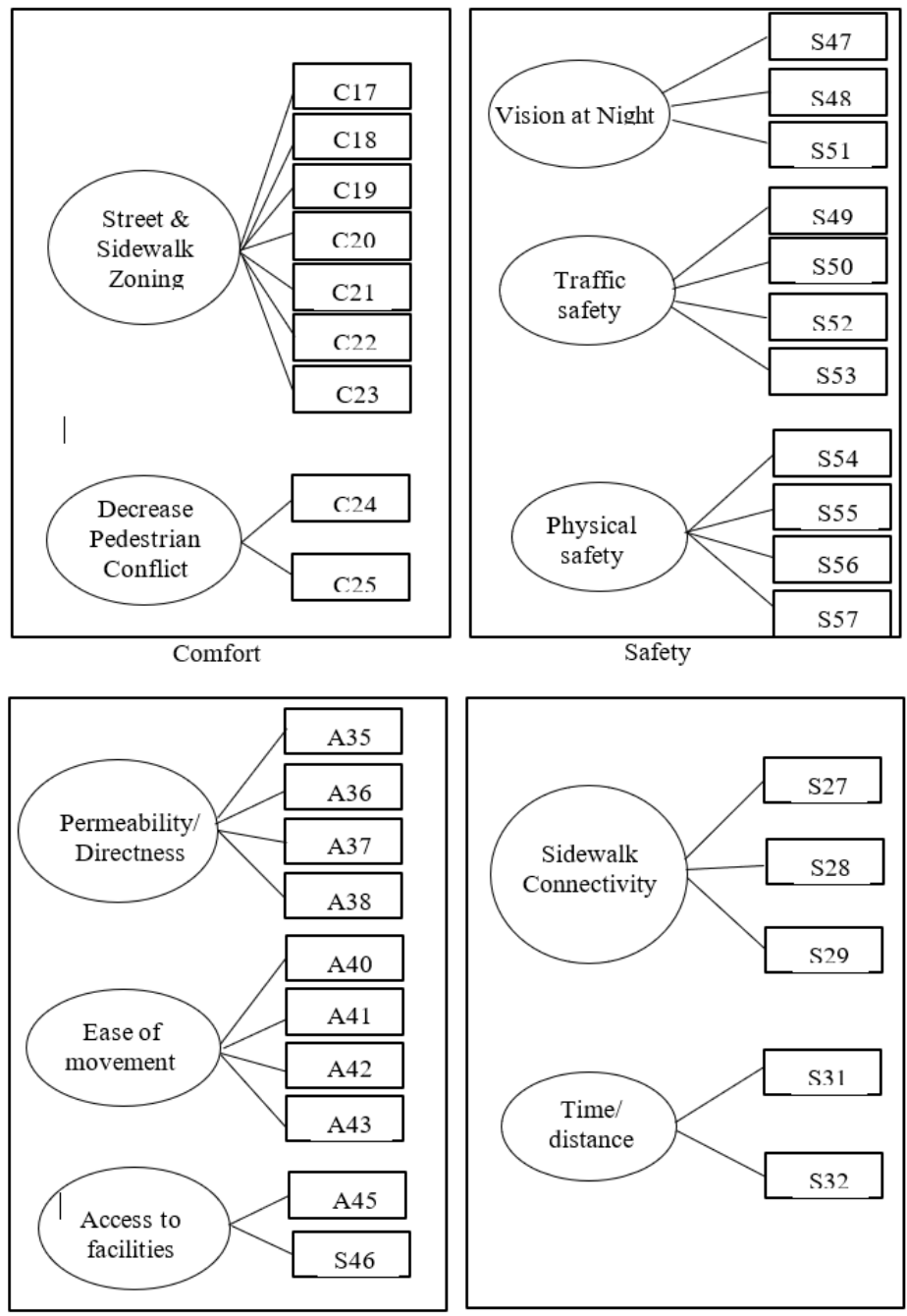

Accessibility

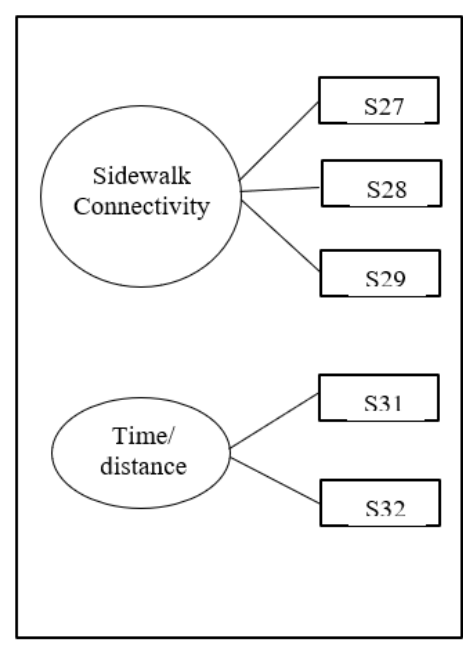

Connectivity

Figure 1 Suggested Name for Latent Variables - Component of Street Walkability

The third walkability factor is accessibility. In this study, accessibility was found to be influenced by three aspects; i) permeability/directness, ii) ease of movement and iii) access to facilities. Street permeability and directness are enhanced through planting locations, types and arrangements. For instance, tree canopies and trunks function as walls and 'roof' to create more defined street spaces. This creates an increase in pedestrian accessibility, frames the pedestrians' vision while walking, and eases their movements and activities. Signage execution and sidewalk links to the nearest facilities help to enhance 
street accessibility on the campus. Land use such as hostels, faculties and bus stops need to be connected appropriately and should be easily accessed by pedestrians within the campus area to increase the level of street accessibility.

Connectivity is the fourth street walkability factor, which is improved through a well-connected sidewalk, implementation of an adequately paved desired pathways and an even sidewalk surface. A well-connected sidewalk is a sidewalk that links to each other without any separation elements or sudden stops. Sidewalk design should consider the shortest path possible for pedestrians to move from one place to another. Each desired path found within the campus should be appropriately paved. In sum, even though comfort appears to be the most significant factors of a walkable street, this does not indicate that other walkability factors are less significant. It is crucial that these factors co-exist and complement each other for a street to be considered as walkable.

\section{CONCLUSION}

The findings of this study produce significant implications for future practices on walkable street design. This study also reveals various potentials of streetways in becoming a part of a successful open space through a well-designed campus streetscape in the future. Moreover, the empirical findings in this research have provided a new understanding of the street function. Aside from its fundamental function as space connectors, streets offer broader opportunities for various pedestrian activities, which consist of passive and active activities. This would contribute to students' social and physical development. The research has also proven that pedestrian walking activities are influenced by streets' physical environment, particularly the composition and the selection of streetscape elements. Recognising the fact that a walkable street provides numerous benefits and more sustainable ways for students to access the campus's grounds, the injection of four walkability factors identified from this study might offer a new paradigm to the campus street environment.

This study concludes that street walkability can only be achieved through the assessment of streetscape elements in the campus by taking into consideration the pedestrian or user's preferences and needs. Greater efforts and attention are needed to be invested towards understanding pedestrian's preferences and to encourage them to walk within the campus as such improvements would make pedestrians become more attached and connected to the street environment. 
Nor Zalina Harun, Amanina Nashar \& Syahriah Bachok

Walkability Factors for A Campus Street

\section{REFERENCES}

Afsar, B., Mohd Yazid M. Y., \& Mohd Johari M. Y., (2015). Assessing essential facilities for daily walking in a tropical campus. Journal of Advances in Environmental Biology, 9(4), 76-78.

Appleyard, B. S. (2003). Planning safe routes to school: How will my child get to and from school? Journal of Planning, 69(5), 34-37.

Brian, S. E., \& Susan, H. L. (2008). Built environment correlates of walking: A review. Medicine and Science in Sports and Exercise, 40(7), 550-566.

Clark, A. F., Scott, D. M. \& Yiannakoulias, N. (2013). Examining the relationship between active travel, weather, and the built environment: A multilevel approach using a GPS-enhanced dataset. Transportation, 41, 325-338.

Galanis A., \& Nikolaos, E. (2011). Evaluation of the pedestrian infrastructure using walkability indicators. WSEAS Transactions on Environment and Development, 12(7), 385-394

Gehl, J., \& Gemzre, L., (1996). Public spaces, public life. Copenhagen: Danish Architectural Press and the Royal Danish Academy of Fine Arts.

Handy, S., Xinyu, C., \& Mokhtarian, P. L. (2005). Correlation or causality between the built environment and travel behavior: Evidence from Northern California. Transportation Research Part D: Transport and Environment, 10(6), 427-444.

Jacob, A. B. (1993). Great streets. Cambridge: The MIT Press.

Litman, T. (2014). Economic value of walkability. World Transport Policy and Practice, $10(1), 5-14$.

Miyakoda, A. (2004). A pedestrian friendly environment for Downtown Baton Rouge (Master thesis). B.D. Kobe Design University.

Moayedi, F., Zakaria, R., Bigah, Y., Mustafar, M., Che Puan, O., Zin, I. S., Klufallah, M. M. A. (2013). Conceptualizing the indicator for sustainable transportation. Journal of Technology, 65(3), 85-90.

Mohd Syazwan, S., Baba, M. D., Aqbal, H. A., Azhar, H., Zulhadi, M., \& Allyana, S. M. R. S. (2018). Revisiting pedestrian casualties in Malaysia and the escalating new threats. Malaysian Journal of Public Health Medicine, 18(Special issue 2), 104 110.

Lee, C., \& Moudon, A. V. (2006). Correlates of walking for transportation or recreation purposes. Journal of Physical Activity \& Health, 3(1), 77-98.

Bahari, N. I., Arshad, A. K., \& Yahya, Z, (2013). Assessing the pedestrians' perception of the sidewalk facilities based on pedestrian travel purpose. IEEE 9th International Colloquium on Signal Processing and its Applications, 27-32.

Ja'afar, N. H., Sulaiman, A. B., \& Shamsuddin, S. (2012). The contribution of landscape features on traditional streets in Malaysia. Procedia Social and Behavioral Sciences, 50, 643-656.

Rahman, N.A., Shamsudin, S., \& Ghani, I., (2014). What makes people use the street? Towards a liveable urban environment in Kuala Lumpur City Centre. Procedia Social and Behavioral Sciences, 170, 624-632.

Harun, N.A, \& Nashar, A. (2016). Developing a framework for streetscape design to promote walkability in Malaysian Campus. Advance Science Letter, 23(4), 2761 2765 . 
Owen, N., Humpel, N., Leslie, E., Bauman, A., \& Sallis, J. F. (2004). Understanding environmental influences on walking: Review and research agenda. American Journal of Preventative Medicine, 27(1), 67-76.

Park, S. (2008). Defining, measuring, and evaluating path walkability, and testing its impacts on transit users' mode choice and walking distance to the station (PhD Dissertation). University of California Transportation Center, Berkeley.

Rahimiashtiani, Z., \& Ujang, N. (2013). Pedestrian satisfaction with aesthetic, attractiveness and pleasurability: Evaluating the walkability of Chaharagh Abbasi Street in Isfahan, Iran. International Journal on Sustainable Tropical Design Research \& Practice, 6 (2), 13-22.

Sallis, J. F., Frank, L. D., Saelens, B. E., \& Kraft, M. K. (2004). Active transportation and physical activity: opportunities for collaboration on transportation and public health. Transportation Research Part A, 38(4), 249-268.

Shamsuddin, S., Sulaiman, A., \& Ja'afar, N. H. (2007). The city and the identity of streets: The criteria for success of the traditional shopping streets in Malaysia. Regional Architecture and Identity in the Age of Globalization Proceeding of CSAAR 2007, 699-710.

Speck, J. (2012) . Walkable city: How downtown can save America - One step at a time. New York: Farrar, Straus and Giroux.

Yap, Y. C., Usman, I., Tahir, M., \& Abidin, IS. Z. (2010). Assessment of Perbadanan Putrajaya office ground based on urban open space design guideline. Selected Topics in Energy, Environment, Sustainable Development and Landscaping - 6th WSEAS International Conference on Energy, Environment, Ecosystems and Sustainable Development, EEESD'10, 3rd WSEAS International Conference on Landscape Architecture, LA'10, 331-337. 